\title{
Milk Production Performance, Challenges and Opportunities of Dairy Cattle Production in West Hararghe, Oromiya Regional State
}

\author{
Ahmedin Abdurehman Musa1 ${ }^{*}$, Yesihak Yusuf Mummed² \\ ${ }^{1}$ Department of Animal Science, Oda Bultum University, Chiro, Ethiopia \\ ${ }^{2}$ School of Animal and Range Sciences, Haramaya University, Dire Dawa, Ethiopia \\ Email: *ahmedin133@gmail.com
}

How to cite this paper: Musa, A.A. and Mummed, Y.Y. (2020) Milk Production Performance, Challenges and Opportunities of Dairy Cattle Production in West Hararghe, Oromiya Regional State. Open Journal of Animal Sciences, 10, 219-235. https://doi.org/10.4236/ojas.2020.101012

Received: September 18, 2019

Accepted: January 28, 2020

Published: January 31, 2020

Copyright (อ 2020 by author(s) and Scientific Research Publishing Inc. This work is licensed under the Creative Commons Attribution International License (CC BY 4.0).

http://creativecommons.org/licenses/by/4.0/ (c) () Open Access

\begin{abstract}
The study was conducted in West Hararge Zone Oromia Regional State, Ethiopia with the objective to describing the dairy production and reproduction performance, identifying and prioritizing researchable issues which make an impact on the development of dairy sector, identifying factors influencing dairy production, constraints and opportunities and forwarding suggestions for the development of dairy sector. Two districts from midland and lowland agro-ecology were purposively selected. Moreover, two kebeles were also selected purposively from each district based on dairy cattle population and accessibility. A total of 120 households were selected for survey data collection from the three agro-ecologies. For the monitoring study, 4 lactating cows in each lactation stage for each rural kebeles as well as for each breed were used. A total of 112 lactating cows were used. The result of the study indicates that the majority (85.8\%) of respondents use local breed cow for milk production and the remaining $14.2 \%$ of respondents are used cross breed. Average daily milk production was 2.98 litters/day/cow and the average price of one liter milk in the study area at the study period was 23.63 birr. There was a significant difference between the two breeds on the mean age at first calving. Local zebu cow has significantly $(\mathrm{P}<0.05)$ higher mean age at first calving $46.73 \pm 0.30$ than cross breed cows $31.41 \pm 0.53$ at the study area. Cross breed cows had significantly shorter $(14.44 \pm 0.43)$ months of CI than that of local zebu cow $(16.02 \pm 0.29)$. Majority of the respondents ranked feed shortage as the first constraint and also mastitis as the first economically important disease problem.
\end{abstract}




\section{Keywords}

Cattle, Dairy, Milk, Reproduction

\section{Introduction}

Ethiopia is reported to be endowed with the largest livestock population in Africa. The cattle population was estimated at about 59.45 million. The indigenous breeds accounted for 98.2 percent, while the hybrids and pure exotic breeds were represented by 1.62 and 0.18 percent, respectively [1].

In spite of such a substantial potential, the dairy sector is not developed to the expected level. The annual growth rate in milk production of $1.2 \%$ falls behind the annual human population growth estimated at 3 percent [2].

The performances of the subsector become poor [3] [4] and farmers are not economically benefited out of it to the extent at which ought to be. Because the breed types are almost entirely of the zebu cattle that are low sources of milk, various influences of environmental factors on the health [4] [5] and the limited impact of Ethiopian government dairy development policy on the growth of the sector as a whole, even in the areas where the private sector investments in the dairy industry encouraged [6].

Besides these challenges on the sector, there is a great potential to develop smallholder dairy schemes in peri-urban and urban areas of Ethiopia [7]. As dairying plays a significant role in the lives of the urban and peri-urban poor households, proper policy implementation of the dairy sector can therefore contribute significantly to poverty alleviation as well as, availability of food and income generation [8]. There are also a very small number of crossbred dairy cows that are milked to provide the family with fresh milk, butter and cottage cheese [9].

In West Hararghe zone, dairy development package interventions have been going on for the past decades and the number of farmers owning local and crossbred dairy cattle and engaging on milk production and marketing has increased over years (west Hararghe zone Livestock development Bureau). To develop appropriate interventions and assist smallholder milk producers requires a clear understanding of the dairy production status and associated constraints. Little is known about the dairy production status, factors influencing dairy production, constraints and opportunities. Thus it is justifiable to generate scientific information on the current dairy production and the major constraints of dairy cattle in the study area. So, in order to attain sustainable dairy development; understanding the current dairy production performances of the particular area and implementing an appropriate intervention are a pre-requisite.

Therefore, this study was carried out with the following objectives;

Describing the dairy cow production and reproduction performance.

Identifying and prioritizing researchable issues which make an impact on the 
development of dairy sector.

$>$ Identifying factors influencing dairy production, constraints and opportunities.

Forwarding suggestions for the development of dairy sector.

\section{Materials and Method}

\subsection{Description of the Study Area}

The study was conducted at west Hararghe zone from February, 2017 to January, 2018. The zone was located to the eastern part of Ethiopia and in Oromia Regional State, $317 \mathrm{~km}$ far from Addis Ababa. West Hararghe Zone shared boarder with Somali and Afar National Regional State in north, East Hararghe Zone in east, Bale Zone in south and East Showa and Arsi zone in West. West Hararghe Zone is located between $9^{\circ} 52^{\prime} 15^{\prime \prime}-9^{\circ} 28^{\prime} 43^{\prime \prime} \mathrm{N}, 40^{\circ} 03^{\prime} 33^{\prime \prime}-40^{\circ} 34^{\prime} 13^{\prime \prime} \mathrm{E}$ latitude and longitude, respectively. The zone was located at an altitude of $1200-3600 \mathrm{~m}$ above sea level. It is also characterized by three agro-climatic zones, namely highland (Badda), midland (Bada-dare) and lowland (Gamoji). Lowland relatively covers large surface area takes more percentage (49.51\%), followed by midland (38\%) and highland (12.49\%). There are two rainy seasons: Long rainy season locally called Ganna (June-September) and short rainy season "badhesa" (February-April). The mean annual rain fall of the area is from $650-2000 \mathrm{~mm}$ and average temperature $20.5^{\circ} \mathrm{C}-24^{\circ} \mathrm{C}$ (Figure 1).

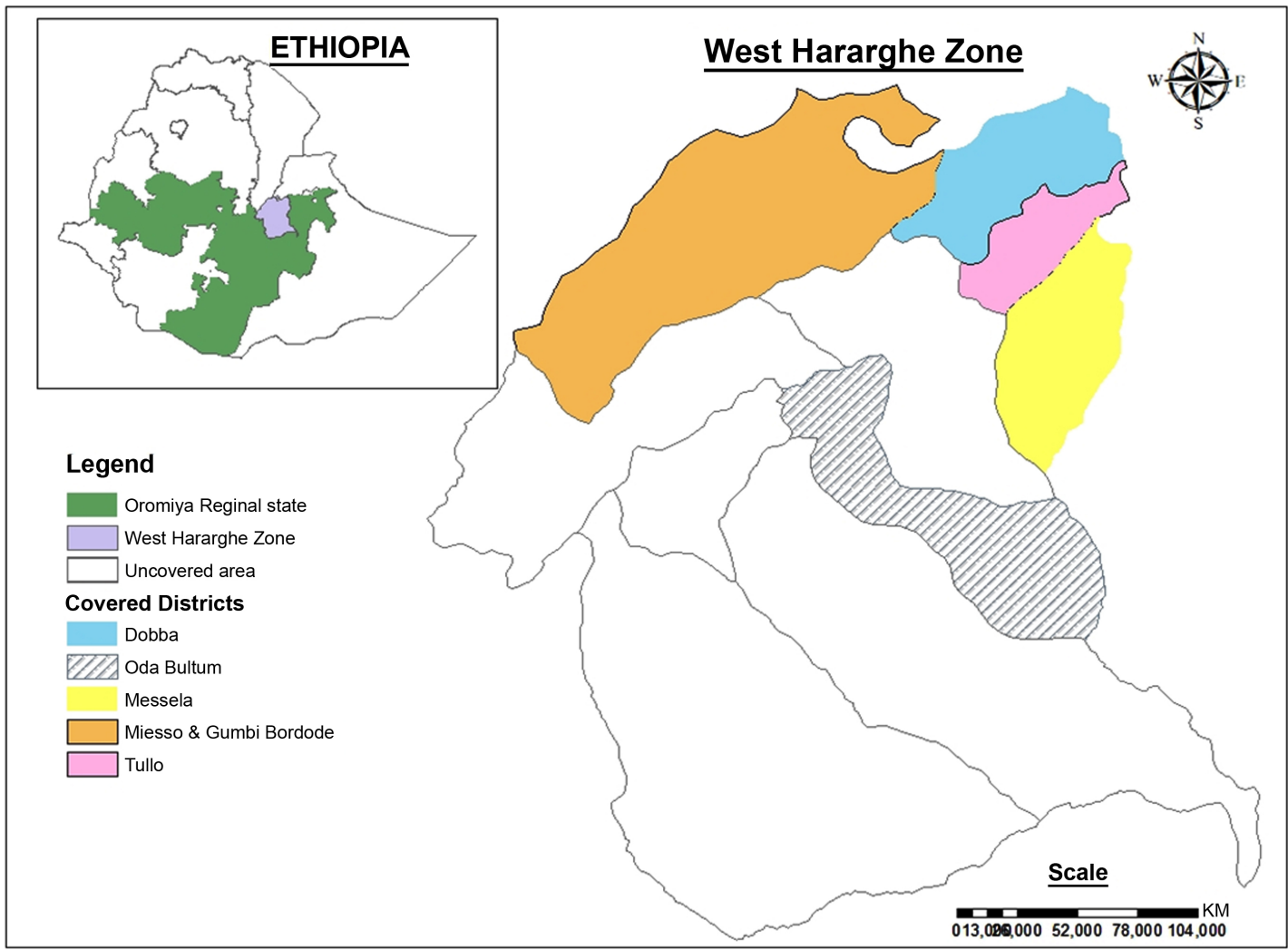

Figure 1. Location of the study area. 


\subsection{Sampling Techniques and Data Collection}

West Hararghe zone consists of 17 districts which are situated in three agro-ecology, namely Highland, Midland and lowland. Two districts from each agro-ecology (Mesela and Doba District from highland, Tullo and Oda Bultum District from midland and Gumbi-Bordode and Mieso District from lowland District) were selected. From each two rural kebeles were also selected purposively based on dairy cattle population, accessibility of the kebele's, area coverage and representativeness for the study areas. The data was collected during the period of March 2017 to January 2018.

For survey data collection group discussion was undertaken with key informants such as elders and Zonal and District Livestock development bureau staff to investigate and have an overview about the overall milk production and marketing system, major dairy disease, challenges and opportunities of dairy cattle production in the area. For the interview, a semi-structured questionnaire was prepared, pretested on two non-random sampled households from each study sites during the rapid field survey and the interview was conducted with the household head. Enumerators were selected and trained from the development agents of the livestock and fisheries office of the Administration. Finally the formal survey was conducted by enumerators under close supervision.

For the two rural kebeles purposively selected from each agro-ecology, 10 households who owned dairy cattle were selected for the interview. Accordingly, a total of 120 households were selected from the three agro-ecologies.

In order to collect data on milk production potential of cow, lactating cow was monitored into different lactation stage with their breed type (local and cross breed). Before the start of milk yield monitoring at field conditions, diagnostic field work was undertaken to identify households that have lactating cows for both or either of local breed or cross breed in the selected rural kebeles. Based on these data, lactating cows were stratified into early ( 1 - 2 months), mid (3 - 4 months), and late (5 - 6 months) lactation stages depending on their average lactation length in order to see the production potential at different stages. For the monitoring study, 4 lactating cows in each lactation stages for each rural kebeles as well as for each breed were used. A total of 112 lactating cows were used. Daily cow milk yield (morning and evening) was measured using a calibrated plastic jogs for a period of one week for all lactation stage.

\subsection{Data Analysis}

Qualitative data derived from direct observations and key informants were examined and presented in the form of discussions. Quantitative data was coded and entered in a computer spread sheets and the Statistical Package for Social Science (SPSS) software version 20 was used for the analysis. Descriptive statistics will run to give frequencies and mean difference was assessed by Tukey multiple comparison by using the GLM Procedure.

\section{Model I}


For milk production and reproductive performance.

$$
Y_{i j k}=\mu+A_{i}+B_{j}+A B_{i j}+C_{i j k}
$$

where

$Y_{i j k}=$ the value of the respective variable mentioned above.

$\mu=$ overall mean of the respective variable.

$A_{i}=$ the effect of $i^{\text {th }}$ agro-ecology $(i=3)$.

$B_{j}=$ the effect of $f^{\text {th }}$ breed $(j=3)$.

$A B_{i j}=$ interaction of $I^{\text {th }}$ agro-ecology $\& f^{\text {th }}$ breed.

$\epsilon_{i j k}=$ random error term.

\section{Model II}

For milk price

$$
Y_{i j k}=\mu+A_{i}+B_{j}+C_{i j k}
$$

where

$Y_{i j k}=$ the value of the respective variable mentioned above.

$\mu=$ overall mean of the respective variable.

$A_{i}=$ the effect of $I^{\text {th }}$ agro-ecology $(i=3)$.

$B_{j}=$ the effect of $f^{\text {th }}$ year category $(j=3)$.

$\epsilon_{i j k}=$ random error term.

\section{Results and Discussion}

\subsection{Milk Production Performance and Lactation Length of the Cows}

Even though indigenous cow are low milk producer, they were the major source of milk in the study area. As indicated in Figure 2, the overall average lactation length for cows in the study area was 8.68 months. Similarly, [10] reported that the overall average lactation length of local and crossbred cows was $8.31 \pm 2.21$ and $8.91 \pm 0.96$ month. According to this result there was no as such variation of lactation length of both local zebu and crossbreed cow within the three agro ecology of the study area except for local zebu cow in midland agro ecology

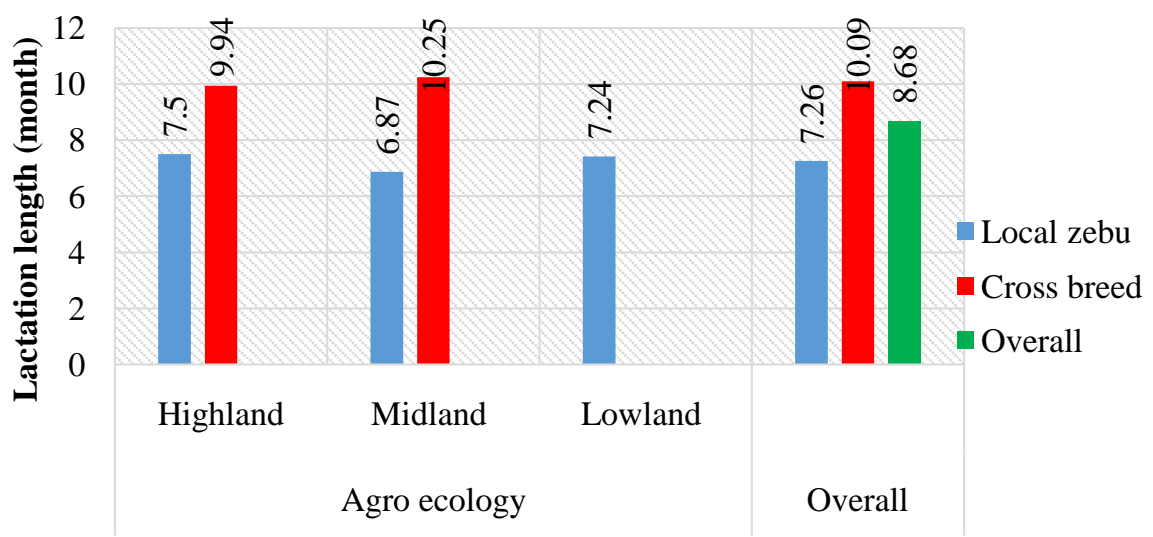

Figure 2. Lactation length of different dairy cattle breed in the three agro ecology of the study area. 
(6.87 months). this variation of lactation length of cow in the study area depends mostly on the management objective of the herder, may the herder need to prolong the lactation length for the sake of continues milk production since milk is the main income generating commodity of the smallholder or dry off the dam at early stage for the purpose of breeding the cows. There was variation of lactation length between the existing local zebu (7.265) month and crossbreed (10.095) month. This result was in line with report of [11] the average lactation length of crossbreed cow was 10.16 months in central highland of Ethiopia. Similarly, [12] reported that the average lactation length for local cows was 7.29 months in mieso district. But lower than the report of [13] that was 9.5 months for local cows in the East Showa zone of Oromia region.

As indicated in (Table 1), Daily milk production per cow in lowland agro-ecology 1.69 liter/cow/day was significantly $(\mathrm{P} \leq 0.05)$ lower than 3.57 and 3.24 liter/day of midland and highland respectively, but there was no significant difference between midland and highland agro-ecology based on the daily milk production of cow. The lower daily milk yield for lowland area in this study was due to the absence of crossing local breed with improved exotic breed and they depend on only local zebu breed for milk production.

Table 1. Mean milk yield (liter/day) of three breeds of cow at three lactation stage under the three agro-ecologies.

\begin{tabular}{|c|c|c|c|c|}
\hline & \multirow{2}{*}{$\mathbf{N}$} & \multirow{2}{*}{ Mean \pm SE } & \multicolumn{2}{|c|}{$\mathbf{9 5 \%}$ confidence interval } \\
\hline & & & Lower Bound & Upper Bound \\
\hline \multicolumn{5}{|l|}{ Agro-ecology } \\
\hline Highland & 48 & $3.24 \pm 0.154^{\mathrm{b}}$ & 2.929 & 3.543 \\
\hline Midland & 48 & $3.57 \pm 0.154^{\mathrm{b}}$ & 3.264 & 3.878 \\
\hline Lowland & 16 & $1.69 \pm 0.266^{\mathrm{a}}$ & 1.164 & 2.228 \\
\hline Sig. & & 0.016 & & \\
\hline \multicolumn{5}{|l|}{ Breed } \\
\hline Local & 48 & $1.94 \pm 0.154^{\mathrm{a}}$ & 1.638 & 2.252 \\
\hline Local $^{*}$ jersey & 32 & $4.17 \pm 0.188^{\mathrm{b}}$ & 3.797 & 4.549 \\
\hline Local $^{\star} \mathrm{HF}$ & 32 & $3.97 \pm 0.188^{\mathrm{b}}$ & 3.592 & 4.344 \\
\hline Sig. & & 0.000 & & \\
\hline \multicolumn{5}{|l|}{ Lactation stage } \\
\hline Early lactation & 112 & $2.99 \pm 0.174^{\mathrm{b}}$ & 2.649 & 3.345 \\
\hline Mid lactation & 112 & $4.12 \pm 0.174^{\mathrm{c}}$ & 3.773 & 4.470 \\
\hline Late lactation & 112 & $2.36 \pm 0.174^{\mathrm{a}}$ & 2.013 & 2.709 \\
\hline Sig. & & 0.000 & & \\
\hline Overall & & $2.98 \pm 0.12$ & 2.959 & 3.361 \\
\hline
\end{tabular}

$\mathrm{SE}=$ standard error, $\mathrm{n}=$ number of cows. ${ }^{\mathrm{a}, \mathrm{b}, \mathrm{c}}$ Means in a column followed by different superscripts are significantly different $(\mathrm{p}<0.05)$. 
There was a significant $(\mathrm{P} \leq 0.05)$ difference between breeds of cow on their daily potential of milk production. Local zebu breed is the lower 1.94 liter/cow/day mean daily milk producer compared with the cross breed of local with jersey (4.17) as well as local with Holstein Friesian (3.97) liter/day. On the other hand jersey and Holstein Friesian cross breed the tested breed did not differ in daily milk production. This result is almost nearest to 4.2 liter/head/day for Barka local breed cross with HF at Holeta and 3.9 liter/cow/day for crossbreed of Barka with Jersey at Bako reported by [14]. While for local cow production performance, this study result was almost agree with the report of [15] who reported that the overall daily milk yield per cow in Borana and Guji zone was 2.08 litre/cow/day and also in Ethiopia the average milk yield per cow per day is about 1.85 liters [3]. According to [16] reported that, on average, 1.5-liter milk per day was obtained from each dairy cows in Sidama Zone which was lower than the present finding for local zebu cow.

There was a significant difference between the results of lactation stage obtained from agro-ecology at the study area on daily milk yield of the cow. According to the result shown under Table 1, on lactation length of the dairy cow, late lactation was significantly $(\mathrm{P}<0.05)$ lowest 2.36 liter/cow/day for mean daily milk production per individual cow, early lactation 2.99 is intermediate, while mid lactation 4.12 liter/cow/day is the most active lactation stage of the cow in the study area. In comparable to this [17] [18] reported that midlactation is the most active stage of daily milk yield followed by early lactation and late lactation. General, the overall daily mean milk yield of cows in the study area was $2.98 \pm$ 0.12 liter/day. In contrary to this [19] reported the daily average milk yield of Abergele cattle to be 0.75 liters which are lower than the present result of study. [20] reported the average daily milk yield of cow was $8.38 \pm 0.47$ liter/day for Holstein-Friesian Cows under Farmer's Management in Hossana Town, Ethiopia which is higher than the current study. The reason for variation of daily milk production in different studies might be due to the effect of feed, health, management aspect and genotype.

\subsection{Trend of Milk Price}

Trends in milk price for ten years back in the current study are shown in (Table 2). There was significant $(P \leq 0.05)$ difference between agro ecology on the price

Table 2. Trend of milk price ten years back at the study area.

\begin{tabular}{ccccccc}
\hline & \multicolumn{3}{c}{ Agro ecology } & \multirow{2}{*}{ Total } \\
\cline { 2 - 4 } Price of one litter milk & Highland & Midland & Lowland & \multirow{2}{*}{ Sig. } & \\
\cline { 2 - 4 } \cline { 2 - 4 } & Mean \pm SD & Mean \pm SD & Mean \pm SD & & Mean \pm SD \\
\hline 10 years back & $2.91 \pm 1.17^{\mathrm{b}}$ & $3.02 \pm 1.21^{\mathrm{b}}$ & $2.05 \pm 0.31^{\mathrm{a}}$ & 0.000 & $2.66 \pm 1.07$ \\
5 years back & $11.60 \pm 0.81^{\mathrm{a}}$ & $14.02 \pm 1.80^{\mathrm{b}}$ & $10.85 \pm 2.51^{\mathrm{a}}$ & 0.000 & $12.15 \pm 2.28$ \\
At present day & $23.60 \pm 3.02^{\mathrm{ab}}$ & $24.50 \pm 1.08^{\mathrm{b}}$ & $22.80 \pm 2.43^{\mathrm{a}}$ & 0.006 & $23.63 \pm 2.41$ \\
\hline
\end{tabular}

${ }^{\mathrm{a}, \mathrm{b}}$ Means in a row followed by different superscripts are significantly different $(\mathrm{p}<0.05)$. Sig. $=$ significant value, $\mathrm{SD}=$ standard deviation. 
of milk for previous ten years. According to the result of the respondent the price of one liter milk was significantly $(\mathrm{P} \leq 0.05)$ lower in lowland 2.05 than highland 2.91 and midland 3.02 birr per litter at ten years back. Similarly the price of one litter milk was significantly $(\mathrm{P} \leq 0.05)$ higher in midland 14.02 than highland 11.6 and lowland 10.85 five years back respectively. But at present day the price of one litter milk was significantly $(\mathrm{P} \leq 0.05)$ higher in midland 24.5 than lowland 22.8 but there was no significant difference between highland and lowland as well as highland and midland of market price of one litter milk at the study area during the study period. Generally, there was an increment of milk price per liter between different years' category and there was slight variation in average price per liter between different surveyed areas within different years in the same categories. The variation between different agro ecology within the same year category may be due to lack of market information, accessibility to urban and peri-urban market and the variation between consumer and milk production and supply in the locality. The average milk price per liter ten years back was 2.66 birr. This result is agreed with report of [15] that average milk price ranges from 1.83 to 2.75 birr per liter in Borana and Guji zone. [21] Also reported that the price of milk in Addis Ababa varies from birr 2.50 to 2.75 birr. Five years back the price of one liter of milk on average is 12.15 birr. In line with this [22] reported that, the price of raw milk per liter in different towns of Ethiopia ranges from ETB 5.00 in DebreBirhan and Fiche to ETB 12.00 in Humera. The average price of one liter milk in the study area at present is $23.63 \mathrm{birr}$. Therefore, this indicates that the amount of milk produced is under the consumers demand in this area and the livestock sector must have to strengthen their strategic plan on improving dairy production of the area.

\subsection{Reproductive Performance of Dairy Cows}

\subsubsection{Age at First Calving}

As indicated in the (Table 3), the present study result indicates that the overall mean month of age at first calving of cow was 40.63 months, which is almost similar with 40.44 reported by [23] and 39.2 months reported by [11] in Ethiopia and $39.4 \pm 1.7$ months reported by [24] for local cows under farmer's management in and around Mekelle; but higher than the value of age at first calving of $36.48 \pm 0.55$ months reported by [20] in Hosanna town, 35.9 month reported by [25] in Ethiopia as well as 33.27 and 29.28 months reported by [26] [27] in Sri Lanka and Tunisian Holstein-Friesian cows respectively; 33.8 months also reported in Arsi breed in Ethiopia [28]. The mean Age at First Calving revealed in this study was shorter than the mean of 60 months in Begait breed, 53.4 months in Fogera breed and 53 months in Horro breed in Ethiopia [29]; $1729.9 \pm 58.2$ days reported in Boran cows at Tatesa cattle breeding center in Gurage Zone, central Ethiopia [30]; $47.16 \pm 8.7$ months in local cows in Chacha Town and nearby selected kebeles, North Shoa Zone, Amhara Region, Ethiopia by [31]. There was a significant difference between the two breeds on the mean age at first calving. Local zebu cow has significantly $(\mathrm{P}<0.05)$ higher mean age at first 
Table 3. Mean month of age at first calving for dairy cow breed in the three agro-ecology.

\begin{tabular}{ccccc}
\hline & & & \multicolumn{2}{c}{$95 \%$ confidence interval } \\
\cline { 4 - 4 } Age at first calving & $\mathrm{N}$ & Mean \pm SE & Lower Bound & Upper Bound \\
\hline Agro-ecology & & & & \\
Highland & 64 & $41.04 \pm 0.48$ & 37.300 & 39.225 \\
Midland & 62 & $42.54 \pm 0.50$ & 38.243 & 40.223 \\
Lowland & 40 & $46.24 \pm 0.59$ & 44.396 & 46.754 \\
Sig. & & 0.488 & & 47.326 \\
Breed & 120 & $46.73 \pm 0.30^{\mathrm{b}}$ & 46.140 & 32.461 \\
Local & & $31.41 \pm 0.53^{\mathrm{a}}$ & 30.369 & \\
Cross breed & 46 & $\mathbf{0 . 0 0 0}$ & & \\
Sig. & & & & \\
Agro-ecology & & & & \\
Sig. & & $\mathbf{0 . 0 6 2}$ & & \\
Overall & 166 & $\mathbf{4 0 . 6 3 \pm 0 . 2 6}$ & 40.167 & \\
\hline
\end{tabular}

$\mathrm{SE}=$ standard error of mean, sig. = significant, $\mathrm{N}=$ number of observation considered as number of cows, ${ }^{a, b}$ Means in a row followed by different superscripts are significantly different at $(\mathrm{p}<0.05)$.

calving $46.73 \pm 0.30$ than cross breed cows $31.41 \pm 0.53$ at the study area. Cross breed cow available at the study area was the cross breed obtained by crossing local zebu cattle with HF and jersey breed. This result shows that cross breed cow was more economical than indigenous cows; because cross breed cow attain age at first calving 15.23 months earlier than indigenous cow in the agro-climatic condition of west Harahghe zone. This may be due to the genetic difference of the cow. The result obtained in this study is comparable with the report of [24] who concluded that the genetic constitution of the animals influenced reproductive efficiency of the cows. Generally, there was no interaction of breed and agro-ecology on age at first calving and variation in age at first calving due to difference in agro-ecology were statistically non-significant.

\subsubsection{Calving Interval}

The overall mean calving interval for indigenous zebu cows and cross breed cows included in this study was $16.19 \pm 0.25$ months (Table 4). The result obtained in this study is comparable with 16.23 months reported for crossbred dairy cows in different production systems in the central Highlands of Ethiopia [32]. The value obtained in this study is higher than the CI of 14.63 months reported by [24]; 12.43 months reported in Asella town, Oromia regional state, Ethiopia by [33] and $13.4 \pm 5.1$ months in crossbred cattle in and around Gondar, North Western Ethiopia by [34]. This estimated CI in this study was less than $21.36 \pm 3.84$ months in Zebu X Holstein-Friesian crossbred dairy cows in Jimma Town, Oromia, Ethiopia [35]. In this study statistical significant was not observed on the value of $\mathrm{CI}$ for varied agro-ecology, but there was significant ( $\mathrm{P}$ 
Table 4. Mean month of calving interval for dairy cows in the study area.

\begin{tabular}{ccccc}
\hline & & & \multicolumn{2}{c}{$95 \%$ confidence interval } \\
\cline { 4 - 4 } Calving interval & $\mathrm{N}$ & Mean \pm SE & Lower Bound & Upper Bound \\
\hline Agro-ecology & & & & \\
Highland & 65 & $16.18 \pm 0.41$ & 15.565 & 17.195 \\
Midland & 66 & $15.76 \pm 0.41$ & 14.956 & 16.567 \\
Lowland & 40 & $16.67 \pm 0.51$ & 15.664 & 17.686 \\
Sig. & & 0.172 & & 16.608 \\
Breed & & & & 17.337 \\
Local cow & 120 & $16.02 \pm 0.29^{\mathrm{b}}$ & 15.442 & \\
Cross breed cow & 51 & $14.44 \pm 0.43^{\mathrm{a}}$ & 12.546 & \\
Sig. & & $\mathbf{0 . 0 2 4}$ & & 16.692 \\
Agro-ecology*breed & & & & \\
Sig. & & $\mathbf{0 . 4 7 2}$ & & \\
Overall & 171 & $\mathbf{1 6 . 1 9 \pm 0 . 2 5}$ & 14.691 & \\
\hline
\end{tabular}

$\mathrm{SE}=$ standard error of mean, sig. = significant, $\mathrm{N}=$ number of observation considered as number of cows, ${ }^{a, b}$ Means in a row followed by different superscripts are significantly different at $(\mathrm{p}<0.05)$.

$<0.05)$ difference of the mean month value of CI for the two breeds of cows. Cross breed cows had significantly shorter $(14.44 \pm 0.43)$ months of CI than that of local zebu cow $(16.02 \pm 0.29)$. The result obtained in this study agrees with the report of [24] that Indigenous cows had the significantly longer average CI (453.22 \pm 71.81 days) than that of HF crossbreds cows (428.11 \pm 64.32 days) in Gonder. Generally, the calving interval in the present study is above the standard interval of 12 months expected usually considered as ideal for profitable milk production. This longer calving interval might be related to genetic factors, environmental factors, poor husbandry management practices, poor nutrition or failure to detect heat by the farmer. There is a need for future improvement on CI for more economic benefits of dairy cow in the study area. Comparably, as indicated by [24] Indigenous cows are also included in their investigation might be important contributory factor for high CI. Feed shortage, silent estrus and lack of proper heat detection might have other contributory factors for long CI reported in their study. Influence of genetic-constitution of dairy animals on their CI was also reported to be significant in Arsi and Zebu breeds of cows and its crosses with Jersey and Holstein-Friesian in Arsi region of Ethiopia [36] and in indigenous and crossbred cows in private sector in sub-tropical region [37].

\subsection{Major Disease Problems of Dairy Cattle}

There are different diseases that can affect dairy cattle in terms of production and quality in the study area. As indicated in (Table 5), mastitis, Blackleg, Pasteurolosis and Anthrax are the major economically important dairy cattle disease of the area. According to the rank given by respondent for all disease; mastitis 
Table 5. Major disease of dairy cattle in west Hararghe zone.

\begin{tabular}{|c|c|c|c|c|c|c|c|c|c|c|c|c|c|c|c|c|}
\hline \multirow{3}{*}{$\begin{array}{c}\text { Diseases } \\
\text { Priority (\%) }\end{array}$} & \multicolumn{12}{|c|}{ Agro ecology } & \multirow{2}{*}{\multicolumn{4}{|c|}{$\begin{array}{l}\text { Overall } \\
N=120\end{array}$}} \\
\hline & \multicolumn{4}{|c|}{$\begin{array}{c}\text { Highland } \\
\mathrm{N}=40\end{array}$} & \multicolumn{4}{|c|}{$\begin{array}{c}\text { Midland } \\
\mathrm{N}=40\end{array}$} & \multicolumn{4}{|c|}{$\begin{array}{c}\text { Lowland } \\
\mathrm{N}=40\end{array}$} & & & & \\
\hline & $1^{\text {st }}$ & $2^{\text {nd }}$ & $3^{\mathrm{rd}}$ & $4^{\text {th }}$ & $1^{\text {st }}$ & $2^{\text {nd }}$ & $3^{\text {rd }}$ & $4^{\text {th }}$ & $1^{\text {st }}$ & $2^{\text {nd }}$ & $3^{\text {rd }}$ & $4^{\text {th }}$ & $1^{\text {st }}$ & $2^{\text {nd }}$ & $3^{\text {rd }}$ & $4^{\text {th }}$ \\
\hline Mastitis & 45.0 & 40.0 & 12.5 & 2.5 & 52.5 & 47.5 & - & - & 77.5 & 22.5 & - & - & 58.3 & 36.7 & 4.2 & 0.8 \\
\hline Anthrax & 2.5 & 2.5 & 45.0 & 50.0 & - & 2.5 & 20.0 & 77.5 & 2.5 & 5.0 & - & 92.5 & 1.7 & 3.3 & 21.7 & 73.3 \\
\hline Blackleg & 47.5 & 45.00 & 7.5 & - & 12.5 & 52.5 & 32.5 & 2.5 & - & 25.0 & 75.0 & - & 20.0 & 40.0 & 38.3 & 1.7 \\
\hline Pasteurolosis & 5.0 & 12.5 & 35.0 & 47.5 & 35.0 & - & 65.0 & - & 22.5 & 52.5 & 25.0 & - & 20.8 & 21.7 & 41.7 & 15.8 \\
\hline
\end{tabular}

$\mathrm{N}=$ number of respondents, $\%=$ percentage of respondents, $1^{\text {st }}=$ First priority; $2^{\text {nd }}=$ Second priority; $3^{\text {rd }}=$ Third priority; $4^{\text {th }}=$ Forth priority.

$\left(1^{\text {st }}\right)$, Blackleg $\left(2^{\text {nd }}\right)$, Pasteurolosis $\left(3^{\text {rd }}\right)$ and Anthrax $\left(4^{\text {th }}\right)$ with percent of $58.3 \%$, $40.0 \%, 41.7 \%$ and $73.3 \%$ respectively. In line with this (kehdija, 2007) also reported that Mastitis (45.8\%), Anthrax (20.8\%), Pasturolosis (15\%), Diarrhea (9\%), Blackleg (7.5\%), FMD (5\%), and thick infestation were the major diseases that affect cattle in Mieso. Similar to this [35] [38] reported that mastitis is the major health problem in dairy cattle production.

According to the discussion made with focus group the treatment of those disease may be call for veterinary service or by traditional method of treatment. Infertility also traditionally treated by the farmers in the study area. As information gathered from local farmers the means of treating infertility traditionally was by restricting feeding because they believe that if the heifers was over fattened the heifer accumulate fat on their uterus that will interrupt with egg fertilization so in order to adjust the physiological process of uterus they inforce the animal to loss the weight by restricting the feed.

\subsection{Challenges of Dairy Cattle Production}

According to the respondents there were different challenges faced in dairy production in the study area. These include shortage of feed, shortage of water, inadequate access to veterinary drugs and services, lack of improved dairy animals and inadequate extension service (Table 6). The producers in this area was asked to prioritize or rank those mentioned problems based on their severity and listed as feed and water scarcity (43.3\%) was the first challenge for dairy development followed by lack of improved dairy cattle (43.3\%) for milk production they depend on almost indigenous cow specially in lowland part of this are there was no cross breed to improve milk production at all but very small number of farmers were getting access to improve milk production by crossing local cow with exotic or cross breed bull through artificial insemination, limited access to veterinary services $(51.7 \%)$ were also the next problems identified and the last was extension service $(52.5 \%)$ due to the distance to veterinary service, irregular visit by the veterinarian for vaccination and giving treatment for sick animals, due to shortage of animal health technician. The shortage of feed and water depend on the availability of rainfall in all agro ecology of the study 
Table 6. Challenges of dairy cattle production.

\begin{tabular}{|c|c|c|c|c|c|c|c|c|c|c|c|c|c|c|c|c|}
\hline \multirow{3}{*}{$\begin{array}{l}\text { Challenges } \\
\text { Priority (\%) }\end{array}$} & \multicolumn{12}{|c|}{ Agro ecology } & \multirow{2}{*}{\multicolumn{4}{|c|}{$\begin{array}{c}\text { Overall } \\
\mathrm{N}=120\end{array}$}} \\
\hline & \multicolumn{4}{|c|}{$\begin{array}{l}\text { Highland } \\
\mathrm{N}=40\end{array}$} & \multicolumn{4}{|c|}{$\begin{array}{c}\text { Midland } \\
\mathrm{N}=40\end{array}$} & \multicolumn{4}{|c|}{$\begin{array}{c}\text { Lowland } \\
\mathrm{N}=40\end{array}$} & & & & \\
\hline & $1^{\text {st }}$ & $2^{\text {nd }}$ & $3^{\text {rd }}$ & $4^{\text {th }}$ & $1^{\text {st }}$ & $2^{\text {nd }}$ & $3^{\text {rd }}$ & $4^{\text {th }}$ & $1^{\text {st }}$ & $2^{\text {nd }}$ & $3^{\text {rd }}$ & $4^{\text {th }}$ & $1^{\text {st }}$ & $2^{\text {nd }}$ & $3^{\text {rd }}$ & $4^{\text {th }}$ \\
\hline Feed \& $\mathrm{H}_{2} \mathrm{O}$ shortage & 55.0 & 32.5 & 12.5 & - & 45.0 & 32.5 & 22.5 & - & 30.0 & 2.5 & 37.5 & 10.0 & 43.3 & 22.5 & 24.2 & 10.0 \\
\hline Improved breed & 32.5 & 67.5 & - & - & 32.5 & 50.0 & - & 17.5 & 40.0 & 12.5 & 30.0 & 17.5 & 35.0 & 43.3 & 10.0 & 11.7 \\
\hline Vet. Service & - & - & 57.5 & 42.5 & - & 17.5 & 82.5 & - & 30.0 & 55.0 & 15.0 & - & 10.0 & 24.2 & 51.7 & 14.2 \\
\hline Extension service & 12.5 & - & 42.5 & 45.0 & 22.5 & - & 17.5 & 60.0 & - & 30.0 & 17.5 & 52.2 & 11.7 & 10.0 & 25.8 & 52.5 \\
\hline
\end{tabular}

$\mathrm{N}=$ number of respondents, $\%=$ percentage of respondents, $1^{\text {st }}=$ First priority; $2^{\text {nd }}=$ Second priority; $3^{\text {rd }}=$ Third priority; $4^{\text {th }}=$ Forth priority.

area in general and in lowland part of the study area in particular. Feed shortage in highland and midland agro ecology depends on availability of pasture land, pasture land or grazing land is influenced by expansion of cultivation land.

Generally, feed shortage was the major and the first challenge or constraint of dairy production in this area. The causes for shortage of feed in the area was loss of pasture land and replaced by crop cultivation mostly in highland and midland part and reduced annual rain fall and recurrent drought in lowland area. Similarly, [39] reported that, inadequate supply of quality feed is the major factors limiting dairy productivity in different parts of Ethiopia.

Even though, there was feed and genetic improvement challenge, the extension service of the sector to cope up this limitation was very week.

\subsection{Opportunities of Dairy Cattle Production}

Although many problems and constraints that may hinder the development of the dairy sector were identified in the area, the interviewed households were willing to continue expand and/or involve in dairying in the future. Because they understood that dairy farming supports livelihoods of society under low input production system, generates income and creates employment opportunity under market oriented production system.

Other opportunities are increasing ever sustaining demand by the community for milk and milk products and encouraging price for these products. Particular attention should be paid to increasing the role of women in dairy development, since the study shows that they play a major role in dairy production and marketing. Highland and midland area are suitable for cross breed cow. Farmers are willing to accept new technologies to improve milk production like improved forage and artificial insemination in highland and midland agro-ecology. Whereas farmers in lowland agro-ecology have indigenous knowledge and skills on breed selection for well performing cow on milk yield. In the study area farmers were trying to use some species of improved forage and they respond that they have interest to invest in dairy sector if improved feed is available. Therefore, feed is the very important asset to participate in dairy sector. Similarly, improved feeding is crucial to provide satisfactory environment for animal growth and 
feed supplements stimulate higher milk productivity as reported by [40]. There is strong culture of consumption of dairy products in this study area. In addition to raw milk, milk products such as butter and fermented milk (yogurt) are also commonly consumed. In the same way, the large human population and very high rate of urbanization, improved income in some segments of the society, are also among the major driving forces that dramatically increase the demand for milk and milk products [18] [41] [42].

\section{Conclusion}

The overall average lactation length for cows in the study area was 8.68 months and indigenous zebu cow was the major source of milk in this zone. There was a significant $(\mathrm{P} \leq 0.05)$ difference between breeds of cow, agro-ecology and lactation stage on their daily potential of milk production. Local zebu breed is the lower 1.94 liter/cow/day mean daily milk producer compared with the cross breed of local with jersey (4.17) as well as local with Holstein Friesian (3.97) liter/day. But there was no such variation between the cross of local zebu with Jersey and Holstein. The overall mean milk yield per day was 2.98 liter/day. Cross breed cow was more economical than indigenous cows; because cross breed cow attains age at first calving 15.23 months earlier than indigenous cow in the agro-climatic condition of west Harahghe zone. The calving interval in the present study is above the standard interval of 12 months expected, so it is not economically profitable milk production. Mastitis, Blackleg, Pasteurolosis and Anthrax are the major economically important dairy cattle disease of the area. Feed shortage was the major and the first challenge of dairy production in west Hararghe that resulted from loss of pasture land and replaced by crop cultivation mostly in highland and midland part and reduced annual rainfall and recurrent drought in lowland part of the zone.

\section{Recommendation}

Enhancing the capacity of veterinary technician both technically and materially will help in controlling the outbreak of the disease so attention should be given.

* Short term training for districts' experts, development agents and farmers on dairy production, processing and marketing is advantageous.

Future researchable issues which make an impact on the development of dairy sector.

$\checkmark$ Milk production-based ration formulation research should have to be done and/or adopted from different agro-ecology of the area.

$\checkmark$ Identifying the prevalence of major dairy disease based on appropriate systematic sample collection in west Hararghe zone will be very important.

$\checkmark$ Livestock sector has been applying their efforts to increase milk production for the past several years through annual and strategic plane but still the outcome of this plan was not as much, as country and particularly in west 
Hararghe zone. Identifying the point of faller to improve the development of the sector is the major area of future research.

\section{Acknowledgements}

The authors would like to express the deep gratitude to Oda Bultum University for funding and facilitating research logistics of this research Work. The authors also like to thank West Hararghe zone Livestock and fisheries development office staffs specially Mohammed Ahmed (DVM) and Kedir Adem as well as all the staffs of the six (Tullo, Doba, Oda Bultum, Mesela, GumbiBordode and Mieso) Livestock and fisheries development offices of the districts' included in the project as well as Development Agents specially (DAs from Animal Science) department who participated in the project for their kind facilitation and support at the time of data collection.

\section{Conflicts of Interest}

The authors declared that there is no conflict of interest between authors and organizations.

\section{References}

[1] CSA (Central Statistical Agency) (2017) Federal Democratic Republic of Ethiopia. Livestock and Livestock Characteristics (Private Peasant Holdings).

[2] GRM International BV (2007) Livestock Development Master Plan Study. Phase I Report-Data Collection and Analysis. Volume 1-Dairy.

[3] CSA (Central Statistical Agency) (2011) Agricultural Sample Survey 2010/11 [2003 E.C.]. Volume II. Report on Livestock and Livestock Characteristics (Private Peasant Holdings). Addis Ababa, Ethiopia.

[4] Central Statistical Agency (CSA) (2013) Agricultural Sample Survey. Livestock, Poultry and Beehives Population (Private Peasant Holdings). Federal Democratic Republic of Ethiopia, Central Statistical Authority (CSA), Addis Ababa, Ethiopia. http://ochaonline.un.org/ethiopia

[5] CARE-Ethiopia (2009) Value Chain Analysis of Milk and Milk Products in Borana Pastoralist Area. CARE-Ethiopia Regional Resilience Enhancement against Drought Project by YONAD Business Promotion and Consultancy PLC, Addis Ababa, Ethiopia.

[6] Staal, S.J., Pratt, A.N. and Jabbar, M. (2008) Dairy Development for the Resource Poor. Part II: Kenya and Ethiopia Dairy Development Case Studies. PPLPI (Pro-Poor Livestock Policy Initiative), Working Paper No. 44-2, ILRI (International Livestock Research Institute), Nairobi, Kenya.

[7] Belay, D., Yisehak, K. and Janssens, G.P. (2011) Analysis of Constraints Facing Urban Dairy Farmers and Gender Responsibility in Animal Management in Jimma Town. Libyan Agriculture Research Center Journal International, 2, 155-160.

[8] Yitaye, A., Wurziger, M., Azage, T. and Zollitsch, W. (2007) Urban and Peri-Urban Farming Systems and Utilization of the Natural Resources in the North Ethiopian Highlands. International Agricultural Research for Development Conference, University of Kassel-Witzenhausen and University of Gottingen, October 9-11.

[9] Belete, A. (2006) Studies on Cattle Milk and Meat Production in Fogera Woreda: 
Production Systems, Constraints Opportunities for Development. Debub University, Awasa, Ethiopia.

[10] Muluye, M. (2016) Milk Production and Reproductive Performance of Local and Crossbreed Dairy Cows in Selected Districts of West Gojam Zone, Amhara Region, Ethiopia. Bahir Dar University, Bahir Dar, Ethiopia.

[11] Tadesse, B., Zelalem, Y., Alemu, G. and Sebsibe, D. (2011) Milk Yield Performance of Two and Three Breed Crosses of Dairy Cattle in the Central Highland of Ethiopia. Journal of Agriculture and Development, 2, 59-74.

[12] Kedija, H. (2007) Characterization of Milk Production System and Opportunity for Market Orientation: A Case Study of Mieso District, Oromia Region, Ethiopia. Haramaya University, Haramaya, Ethiopia.

[13] Lemma, F., Fekadu, B. and Hegde, P. (2005) Traditional Milk and Milk Products Handling Practices and Preservation Methods in Three Districts of East Shoa Zone of Oromia. In: Yimegnuhal, A. and Degefa, T., Eds., Proceedings of the 12 th Annual Conference of the ESAP, Participatory Innovation and Research: Lessons for Livestock Development, Addis Ababa, Ethiopia, 29-37.

[14] Kategile, J.A. and Mubi, S. (1993) Future Livestock Industries in East and Southern Africa. In: Proceedings of a Workshop Held at Kadoma Ranch Hotel, ILCA (Internationa Livestock Center for Africa), Addis Ababa, Ethiopia, 227.

[15] Yohannes, U. (2015) Status of Dairy Cattle Production in Borana and Guji Zone, Ethiopia. International Journal of Innovative Research \& Development, 4, 9-16.

[16] Tsegay, L., Agengew, A. and Ashenafi, S. (2015) Dairy Cattle Production at Small Holder Level in Sidama Zone Selected Districts, Southern Ethiopia. Food Science and Quality Management, 40, 35-42.

[17] Lijalem, T. (2016) Production and Reproduction Performances of Local Dairy Cattle: In the Case of Rural Community of Wolaita Zone, Southern Ethiopia. Journal of Fisheries \& Livestock Production, 4, 176. https://doi.org/10.4172/2332-2608.1000176

[18] Minale, G. and Yilkal, T. (2015) Constraints and Opportunities of Dairy Cattle Production in Chencha and Kucha Districts, Southern Ethiopia. Journal of Biology, Agriculture and Healthcare, 5, 38-43.

[19] Merha, Z. (2006) Genetic Diversity in Northern Ethiopian Cattle Breed: An On-Farm and Molecular Characterization, Ph.D. Dissertation, Agricultural University, Wageningen, The Netherlands.

[20] Haftu, K. (2015) Productive and Reproductive Performance of Holstein-Friesian Cows under Farmer's Management in Hossana Town, Ethiopia. International Journal of Dairy Science, 10, 126-133. https://doi.org/10.3923/ijds.2015.126.133

[21] Desta, B.K. (2002) Analyses of Dairy Cattle Breeding Practices in Selected Areas of Ethiopia, Humboldt-Universität, Berlin. Unpublished PhD Dissertation Manuscript, 175.

[22] Land, O. (2010) Dairy Value Chains, End Markets and Food Security; The Next Stage in Dairy Development for Ethiopia. Cooperative Agreement, Addis Ababa, Ethiopia, 88.

[23] Tassew, A. and Seifu, E. (2009) Smallholder Dairy Production System and Emergence of Dairy Cooperatives in Bahir Dar Zuria and Mecha Woredas, Northwestern Ethiopia. World Journal of Dairy and Food Sciences, 4, 185-192.

[24] Kumar, N., Alemayehu, E., Berihu, G. and Endale, B. (2014) Reproductive Performance of Indigenous and HF Crossbred Dairy Cows in Gondar, Ethiopia. IOSR 
Journal of Agriculture and Veterinary Science, 7, 56-61. https://doi.org/10.9790/2380-07155661

[25] Kidane, A.B., Delesa, K.E., Mummed, Y.Y. and Tadesse, M. (2019) Reproductive and Productive Performance of Holstein Friesian and Crossbreed Dairy Cattle at Large, Medium and Small Scale Dairy Farms in Ethiopia. International Journal of Advanced Research in Biological Sciences, 6, 15-29. https://doi.org/10.22192/ijarbs

[26] Kollalpitiya, K., Premaratne, S. and Peiris, B.L. (2012) Reproductive and Productive Performance of Up-Country Exotic Dairy Cattle Breeds of Sri Lanka. Tropical Agricultural Research, 23, 319. https://doi.org/10.4038/tar.v23i4.4867

[27] Ajili, N., Rekik, B., Gara, A.B. and Bouraoui, R. (2007) Relationships among Milk Production, Reproductive Traits and Herd Life for Tunisian Holstein-Friesian Cows. African Journal of Agricultural Research, 2, 47-51.

[28] Gabriel, H.K., John, C.M., Trail, Kurtu, M.Y., Frank, G.W. and Jeffrey, D. (1983) Crossbred Dairy Cattle Productivity in Arsi Region, Ethiopia. ILCA Research Report No 11.

[29] Rege, J.E.O., Ayalew, W., Getahun, E., Hanotte, O. and Dessie, T. (2006) DAGRIS (Domestic Animal Genetic Resources Information System). International Livestock Research Institute, Addis Ababa, Ethiopia. http://dagris.ilri.cgiar.org

[30] Yifat, D., Bahilibi, W. and Desie, S. (2012) Reproductive Performance of Boran Cows at Tatesa Cattle Breeding Center. Advances in Biological Research, 6, 101-105.

[31] Mulugeta, A. and Belayeneh, A. (2013) Reproductive and Lactation Performances of Dairy Cows in Chacha Town and Nearby Selected Kebeles, North Shoa Zone, Amhara Region, Ethiopia. World Journal of Agricultural Sciences, 1, 8-17.

[32] Shiferaw, Y., Tenhagen, B.A., Bekana, M. and Kassa, T. (2003) Reproductive Performance of Crossbred Dairy Cows in Different Production Systems in the Central Highlands of Ethiopia. Tropical Animal Health and Production, 35, 551-561. https://doi.org/10.1023/A:1027377722576

[33] Hunduma, D. (2012) Reproductive Performance of Crossbred Dairy Cows under Smallholder Condition in Ethiopia. International Journal of Livestock Production, 3, 25-28. https://doi.org/10.5897/IJLP11.055

[34] Nibret, M. (2012) Study on Reproductive Performance of Crossbred Dairy Cows under Small Holder Conditions in and Around Gondar, North Western Ethiopia. Journal of Reproduction and Infertility, 3, 38-41. https://doi.org/10.5897/IJLP11.055

[35] Belay, D., Yisehak, K. and Geert, P. (2012) Survey of Major Diseases Affecting Dairy Cattle in Jimma Town, Oromia, Ethiopia. Global Veterinaria, 8, 62-66.

[36] Kiwuwa, G.H., Trail, J.C., Kurtu, M.Y., Worku, G., Anderson, F.M. and Durkin, J. (1983) Crossbred Dairy Cattle Productivity in Arsi Region, Ethiopia. Research Report No. 11, ILCA, Addis Ababa, Ethiopia, 1-29.

[37] Singh, K., Khanna, A.S. and Kanaudia, A.S. (2000) Factor Effecting Lactation Performance and Persistency in Crossbred Cattle. India Journal of Dairy Science, 53, 354-360.

[38] Fasil, N., Terefe, S.J. and Dessie, S. (2016) Major Health Challenges of Dairy Cattle in Hawassa Town SNNPRS, Ethiopia. Journal of Veterinary Science \& Technology, 7, 1-6. https://doi.org/10.4172/2157-7579.1000367

[39] Guya, M.E., Mulu, M.A. and Mumed, Y.Y. (2019) Milk Production, Marketing and Quality in Meta District of Eastern Hararghe Zone, Ethiopia. Journal of Agricultural Science, 11, 535-546. https://doi.org/10.5539/jas.v11n5p535

[40] SNV (The Netherlands Development Organization) (2008) Study on Dairy Invest- 
ment Opportunities in Ethiopia. Addis Ababa, 59.

[41] Azage, T., Gebremedhin, B., Hoekstra, D., Belay, B. and Mekasha, Y. (2013) Smallholder Dairy Production and Marketing Systems in Ethiopia: IPMS Experiences and Opportunities for Market-Oriented Development. IPMS (Improving Productivity and Market Success) of Ethiopian Farmers Project Working Paper 31, ILRI, Nairobi.

[42] Asrat, A., Zelalem, Y. and Ajebu, N. (2013) Characterization of Milk Production Systems in and around Boditti, South Ethiopia. 